\title{
FITOGEOGRAFI PASAK BUMI (Eurycoma longifolia, Jack) PADA KAWASAN HUTAN LINDUNG GUNUNG AMBAWANG BUKIT BENDERA KABUPATEN KUBU RAYA KALIMANTAN BARAT
}

(Phytogeography of Pasak Bumi (Eurycoma longifolia, Jack) on the Protected Forest Area Ambawang hill, Bendera mountain, Kubu Raya Regency, West Kalimantan Province)

\section{Mardon Van Le, Siti Masitoh Kartikawati, Togar Fernando M}

Fakultas Kehutanan Universitas Tanjungpura Pontianak. J1. Daya Nasional Pontianak 78124 E-mail: vanle.mardon@gmail.com

\begin{abstract}
Pasak Bumi (Eurycoma longifolia, Jack.) It is a rare medicinal plant commonly found in Indonesian forests. The purpose of the study was to determine the phytogeography of pasak Bumi in Mount Ambawang Bukit Bendera, Kubu Raya Regency. The study was conducted by survey method with data collection techniques using the census method. The conditions observed included conditions, slope, altitude, and wind direction aspects (North, South, West, East). Then map the census results by measuring stem diameter ( $\mathrm{cm})$, tree height (m), slope (\%), altitude ( $m$ asl), wind direction aspects, and coordinate points. Then true value, with the literature on habitat and phytogeography of pasak Bumi. Based on the results of the study found a total of 91 individuals scattered starting from an altitude of 98-200 $\mathrm{m}$ above sea level, the southernmost most found amounted to 45 individuals, the eastern part numbered 17 individuals, the western part amounted to 18 individuals while in the north with the number 11 individuals. This is because growth is covered by a canopy of dense trees that cover the pasak Bumi plant.
\end{abstract}

Keywords: Eurycoma longifolia, Gunung Ambawang, Kubu Ray, pasak Bumi, phytogeography.

\section{PENDAHULUAN}

Pasak bumi (Eurycoma longifolia, Jack.) merupakan tumbuhan obat langka yang banyak ditemukan di hutan-hutan Indonesia, Malaysia, Thailand, Filipina, Vietnam, dan Birma (Siregar et al. 2003; Minosky2004).Pasak bumi di Indonesia mempunyai beragam nama daerah, antara lain pasak bumi (Kalimantan), widara putih (Jawa), bidara laut, mempoleh (Bangka), penawar pahit (Melayu), dan beseng (Sumatra) (Padua et al. 1999). pasak bumi pada umumnya terbentuk semak atau pohon yang tingginya dapat mencapai 10 meter, berdaun majemuk menyirip ganjil, batangnya berwarna kuning, kulit batang keras dan rasanya sangat pahit.

Berdasarkan keberadaanya, pasak bumi mempunyai rentang penyebaran topografi yang cukup lebar dengan sifat sebaran menyebar berkelompok (Heyne1987; Nuryamin 2000; Julisasi 1992; Kartikawati 2014). Berdasarkan material koleksi pasak bumi di herbarium Bogoriense, pasak bumi dapat ditemukan pada daerah ketinggian $0-700 \mathrm{~m}$ dpl. Gunung Ambawang Bukit Bendera di Kabupaten Kubu Raya termasuk daerah penyebaran pasak bumi ditemukan dengan ketinggian 5-401 m dpl, sebanyak 114 individu (Kartikawati 2014). 
Berdasarkan penelitian sebelumnya menarik untuk diteliti lebih lanjut mengenai fitogeografi pasak bumi yang meliputi kemiringan lereng, ketinggian tempat, dan aspek arah mata angin (Utara, Selatan, Barat, Timur) di Gunung Ambawang Bukit Bendera.

\section{METODE PENELITIAN}

Penelitian ini dilaksanakan pada Areal Gunung Ambawang Bukit Bendera Kabupaten Kubu Desa Sungai Deras Kecamatan Teluk Pakedai, dengan waktu \pm 3 minggu efektif dilapangan mulai tanggal 22 Februari sampai dengan 14 Maret 2018. Adapun alat dan bahan yang digunakan dalam penelitian adalah peta lokasi, kamera, kompas, Gps, pita ukur, parang, ATK, Tally - sheet, haga meter, abney level.

Penelitian dilakukan dengan metode survey dengan teknik pengumpulan data menggunakan metode sensus. Data yang diambil tingkat pertumbuhan pasak bumi mulai dari semai, pancang, tiang, dan pohon yang dicatat adalah semua tumbuhan pasak bumi dan pengamatan yang meliputi diameter batang $(\mathrm{cm})$, tinggi pohon (m), kemiringan lereng (\%), ketinggian tempat (m dpl), aspek arah mata angin (Utara, Selatan, Barat, Timur). Analisis yang dilakukan dengan tabulasi dan memetakan hasil sebaran pasak bumi. Objek penelitian tumbuhan pasak bumi yang ditemui dititik koordinatnya dengan menggunakan GPS, langsung titik koordinat dari masing-masing tumbuhan pasak bumi yang ditemui di gambarkan diatas peta sehingga dapat diketahui sebarannya pada areal Kawasan Hutan Lindung Gunung Ambawang Bukit Bendera..

\section{HASIL DAN PEMBAHASAN}

Hasil pengamatan ditemukan sebanyak 91 individu tersebar mulai dari ketinggian 98-200 m dpl. Jumlah populasi pasak bumi berdasarkan tingkat ketinggian dan kelerengan yang berbeda, dapat dilihat pada Tabel 1.

Tabel 1. Fitogeografi pasak bumi bagian Timur (Phytogeography of the Eastern part of the earth)

\begin{tabular}{|c|c|c|c|c|c|c|c|c|}
\hline \multirow{2}{*}{$\begin{array}{l}\text { Nomor } \\
\text { Pohon }\end{array}$} & \multirow{2}{*}{$\begin{array}{l}\text { Diameter } \\
\text { batang } \\
\text { (cm) }\end{array}$} & \multirow{2}{*}{$\begin{array}{l}\text { Tinggi } \\
\text { (m) }\end{array}$} & \multirow{2}{*}{$\begin{array}{l}\text { Kemiringan } \\
\text { Lereng }(\%)\end{array}$} & \multirow{2}{*}{$\begin{array}{l}\text { Ketinggian } \\
\text { (m dpl) }\end{array}$} & \multirow{2}{*}{$\begin{array}{l}\text { Aspek } \\
\text { Mata } \\
\text { Angin }\end{array}$} & \multicolumn{2}{|c|}{ Koordinat } & \multirow{2}{*}{ Ket. } \\
\hline & & & & & & $\mathbf{X}$ & $\mathbf{Y}$ & \\
\hline PBT1 & 2,707 & 2 & $25-40$ & 110,321 & Timur & 109,288 & $-0,352$ & Pancang \\
\hline PBT2 & 2,229 & 2.2 & $25-40$ & 120,211 & Timur & 109,288 & $-0,352$ & Pancang \\
\hline PBT3 & & 0.5 & $25-40$ & 121,125 & Timur & 109,288 & $-0,352$ & Semai \\
\hline PBT4 & 2,866 & 2 & $25-40$ & 126,155 & Timur & 109,288 & $-0,353$ & Pancang \\
\hline PBT5 & 3,821 & 4 & $25-40$ & 128,124 & Timur & 109,287 & $-0,352$ & Pancang \\
\hline PBT6 & 2,547 & 3.5 & $25-40$ & 128,442 & Timur & 109,288 & $-0,353$ & Pancang \\
\hline PBT7 & 1,910 & 3 & $25-40$ & 128,711 & Timur & 109,287 & $-0,353$ & Pancang \\
\hline PBT8 & 2,229 & 3 & $25-40$ & 129,235 & Timur & 109,287 & $-0,353$ & Pancang \\
\hline PBT9 & 2,547 & 7 & $25-40$ & 130,121 & Timur & 109,288 & $-0,353$ & Pancang \\
\hline PBT10 & 4,458 & 4.5 & $25-40$ & 130,122 & Timur & 109,288 & $-0,353$ & Pancang \\
\hline PBT11 & 3,184 & 3.6 & $25-40$ & 133,221 & Timur & 109,288 & $-0,353$ & Pancang \\
\hline PBT12 & 3,821 & 3.4 & $25-40$ & 134,122 & Timur & 109,288 & $-0,352$ & Pancang \\
\hline PBT13 & 1,910 & 2 & $25-40$ & 134,134 & Timur & 109,287 & $-0,353$ & Pancang \\
\hline PBT14 & 4,140 & 4 & $25-40$ & 135,124 & Timur & 109,287 & $-0,353$ & Pancang \\
\hline PBT15 & 5,095 & 5.2 & $25-40$ & 136,231 & Timur & 109,288 & $-0,353$ & Pancang \\
\hline PBT16 & 3,184 & 4 & $25-40$ & 137,212 & Timur & 109,287 & $-0,353$ & Pancang \\
\hline PBT17 & 5,095 & 3.7 & $15-25$ & 158,307 & Timur & 109,287 & $-0,353$ & Pancang \\
\hline
\end{tabular}


JURNAL HUTAN LESTARI (2019)

Vol. 7 (1) : 363 - 371

Tabel 2. Fitogeografi pasak bumi bagian Barat (Phytogeography of the Western part of the earth)

\begin{tabular}{|c|c|c|c|c|c|c|c|c|}
\hline \multirow{2}{*}{$\begin{array}{l}\text { Nomor } \\
\text { Pohon }\end{array}$} & \multirow{2}{*}{$\begin{array}{l}\text { Diameter } \\
\text { batang } \\
\text { (cm) }\end{array}$} & \multirow{2}{*}{$\begin{array}{l}\text { Tinggi } \\
\text { (m) }\end{array}$} & \multirow{2}{*}{$\begin{array}{l}\text { Kemiringan } \\
\text { Lereng (\%) }\end{array}$} & \multirow{2}{*}{$\begin{array}{l}\text { Ketinggian } \\
\text { (m dpl) }\end{array}$} & \multirow{2}{*}{$\begin{array}{l}\text { Aspek } \\
\text { Mata } \\
\text { Angin }\end{array}$} & \multicolumn{2}{|c|}{ Koordinat } & \multirow{2}{*}{ Ket. } \\
\hline & & & & & & $\mathbf{X}$ & $\mathbf{Y}$ & \\
\hline PBB1 & 1,751 & 3 & $15-25$ & 155,03 & Barat & 109,287 & $\begin{array}{l}-0,353 \\
\end{array}$ & Pancang \\
\hline PBB2 & 1,114 & 3 & $15-25$ & 161,29 & Barat & 109,287 & $-0,353$ & Pancang \\
\hline PBB3 & 0,955 & 2 & $15-25$ & 161,7 & Barat & 109,287 & $-0,353$ & Pancang \\
\hline PBB4 & 0,636 & 3 & $15-25$ & 163,56 & Barat & 109,287 & $-0,353$ & Pancang \\
\hline PBB5 & 4,458 & 4 & $15-25$ & 164,54 & Barat & 109,287 & $-0,353$ & Pancang \\
\hline PBB6 & 1,273 & 2 & $15-25$ & 167,08 & Barat & 109,287 & $-0,353$ & Pancang \\
\hline PBB7 & 2,866 & 4.7 & $15-25$ & 168,25 & Barat & 109,287 & $-0,353$ & Pancang \\
\hline PBB8 & 5,732 & 6 & $15-25$ & 169,04 & Barat & 109,287 & $-0,353$ & Pancang \\
\hline PBB9 & 3,184 & 5 & $15-25$ & 169,26 & Barat & 109,287 & $-0,353$ & Pancang \\
\hline PBB10 & 2,866 & 4.5 & $15-25$ & 175,75 & Barat & 109,287 & $-0,353$ & Pancang \\
\hline PBB11 & 3,184 & 3.5 & $15-25$ & 176,53 & Barat & 109,287 & $-0,353$ & Pancang \\
\hline PBB12 & 3,184 & 3 & $15-25$ & 177,73 & Barat & 109,287 & $-0,353$ & Pancang \\
\hline PBB13 & 3,503 & 3 & $15-25$ & 177,8 & Barat & 109,287 & $-0,353$ & Pancang \\
\hline PBB14 & 1,592 & 7 & $15-25$ & 178,31 & Barat & 109,287 & $-0,353$ & Pancang \\
\hline PBB15 & 1,910 & 4.5 & $15-25$ & 179,85 & Barat & 109,287 & $-0,353$ & Pancang \\
\hline PBB16 & 2,547 & 3.6 & $15-25$ & 180,38 & Barat & 109,287 & $-0,353$ & Pancang \\
\hline PBB17 & 2,292 & 3.4 & $15-25$ & 182,03 & Barat & 109,287 & $-0,353$ & Pancang \\
\hline PBB18 & 2,866 & 5.4 & $15-25$ & 183,81 & Barat & 109,287 & $-0,353$ & Pancang \\
\hline
\end{tabular}

Tabel 3. Fitogeografi pasak bumi bagian Utara (Fitogeography of the northern part of the earth's stake)

\begin{tabular}{|c|c|c|c|c|c|c|c|c|}
\hline \multirow{2}{*}{$\begin{array}{l}\text { Nomor } \\
\text { Pohon }\end{array}$} & \multirow{2}{*}{$\begin{array}{l}\text { Diameter } \\
\text { Batang } \\
\text { (cm) }\end{array}$} & \multirow{2}{*}{$\begin{array}{l}\text { Tinggi } \\
\text { (m) }\end{array}$} & \multirow{2}{*}{$\begin{array}{l}\text { Kemiringan } \\
\text { Lereng }(\%)\end{array}$} & \multirow{2}{*}{$\begin{array}{l}\text { Ketinggian } \\
\text { (m dpl) }\end{array}$} & \multirow{2}{*}{$\begin{array}{l}\text { Aspek } \\
\text { Mata } \\
\text { Angin }\end{array}$} & \multicolumn{2}{|c|}{ Koordinat } & \multirow{2}{*}{ Ket. } \\
\hline & & & & & & $\mathbf{X}$ & $\mathbf{Y}$ & \\
\hline PBU1 & 1,369 & 2.9 & $25-40$ & 98,993 & Utara & 109,288 & $-0,352$ & Pancang \\
\hline PBU2 & 1,273 & 1.98 & $25-40$ & 101,052 & Utara & 109,288 & $-0,352$ & Pancang \\
\hline PBU3 & 1,273 & 1.57 & $25-40$ & 101,737 & Utara & 109,288 & $-0,352$ & Pancang \\
\hline PBU4 & 1,592 & 2 & $25-40$ & 104,011 & Utara & 109,288 & $-0,352$ & Pancang \\
\hline PBU5 & 1,369 & 2.3 & $25-40$ & 105,082 & Utara & 109,288 & $-0,352$ & Pancang \\
\hline PBU6 & 2,229 & 2 & $25-40$ & 105,366 & Utara & 109,287 & $-0,352$ & Pancang \\
\hline PBU7 & 1,910 & 2.4 & $25-40$ & 108,277 & Utara & 109,288 & $-0,352$ & Pancang \\
\hline PBU8 & 1,273 & 3 & $25-40$ & 110,310 & Utara & 109,287 & $-0,352$ & Pancang \\
\hline PBU9 & 3,503 & 4.6 & $25-40$ & 117,045 & Utara & 109,287 & $-0,352$ & Pancang \\
\hline PBU10 & 2,866 & 5.2 & $25-40$ & 117,125 & Utara & 109,287 & $-0,352$ & Pancang \\
\hline PBU11 & 1,401 & 3 & $25-40$ & 120,617 & Utara & 109,287 & $-0,352$ & Pancang \\
\hline
\end{tabular}


JURNAL HUTAN LESTARI (2019)

Vol. 7 (1) : $363-371$

Tabel 4. Fitogeografi pasak bumi bagian Selatan (Biogeography of the southern part of the earth)

\begin{tabular}{|c|c|c|c|c|c|c|c|c|}
\hline \multirow{2}{*}{$\begin{array}{l}\text { Nomor } \\
\text { Pohon }\end{array}$} & \multirow{2}{*}{$\begin{array}{c}\text { Diameter } \\
\text { Batang } \\
(\mathrm{cm})\end{array}$} & \multirow{2}{*}{$\begin{array}{c}\text { Tinggi } \\
(\mathrm{m})\end{array}$} & \multirow{2}{*}{$\begin{array}{l}\text { Kelerengan } \\
\text { Lereng (\%) }\end{array}$} & \multirow{2}{*}{$\begin{array}{c}\text { Ketinggian } \\
\text { (m dpl) }\end{array}$} & \multirow{2}{*}{$\begin{array}{c}\text { Aspek } \\
\text { Mata } \\
\text { Angin }\end{array}$} & \multicolumn{2}{|c|}{ Koordinat } & \multirow[b]{2}{*}{ Ket. } \\
\hline & & & & & & $\mathbf{X}$ & $\mathbf{Y}$ & \\
\hline PBS1 & 3,821 & 4 & $25-40$ & 187,575 & Selatan & 109,286 & $-0,353$ & Pancang \\
\hline PBS2 & 1.751 & 2 & $8-15$ & 189,233 & Selatan & 109,287 & $-0,353$ & Pancang \\
\hline PBS3 & 1.114 & 1.7 & $8-15$ & 189,761 & Selatan & 109,287 & $-0,353$ & Pancang \\
\hline PBS4 & 0,955 & 2 & $25-40$ & 190,276 & Selatan & 109,287 & $-0,353$ & Pancang \\
\hline PBS5 & 0,636 & 2.4 & $25-40$ & 190,766 & Selatan & 109,287 & $-0,353$ & Pancang \\
\hline PBS6 & 4,45 & 3 & $25-40$ & 190,778 & Selatan & 109,287 & $-0,353$ & Pancang \\
\hline PBS7 & 1,273 & 2.7 & $25-40$ & 191,531 & Selatan & 109,287 & $-0,353$ & Pancang \\
\hline PBS8 & 2,866 & 3 & $8-15$ & 191,671 & Selatan & 109,287 & $-0,353$ & Pancang \\
\hline PBS9 & 5,732 & 4.3 & $25-40$ & 191,711 & Selatan & 109,287 & $-0,353$ & Pancang \\
\hline PBS10 & 3,184 & 6 & $8-15$ & 191,780 & Selatan & 109,287 & $-0,353$ & Pancang \\
\hline PBS11 & 1,273 & 5 & $25-40$ & 191,860 & Selatan & 109,287 & $-0,353$ & Pancang \\
\hline PBS12 & 2,229 & 1.5 & $25-40$ & 191,867 & Selatan & 109,287 & $-0,353$ & Pancang \\
\hline PBS13 & 1,592 & 2.3 & $8-15$ & 191,975 & Selatan & 109,287 & $-0,353$ & Pancang \\
\hline PBS14 & 2,229 & 4.3 & $8-15$ & 192,063 & Selatan & 109,287 & $-0,353$ & Pancang \\
\hline PBS15 & 1,910 & 2 & $8-15$ & 192,411 & Selatan & 109,287 & $-0,353$ & Pancang \\
\hline PBS16 & 1,273 & 3 & $8-15$ & 192,709 & Selatan & 109,287 & $-0,353$ & Pancang \\
\hline PBS17 & 1,273 & 2.5 & $8-15$ & 193,056 & Selatan & 109,287 & $-0,353$ & Pancang \\
\hline PBS18 & 0,955 & 1.5 & $8-15$ & 193,151 & Selatan & 109,287 & $-0,353$ & Pancang \\
\hline PBS19 & 1,273 & 1.5 & $8-15$ & 193,330 & Selatan & 109,287 & $-0,353$ & Pancang \\
\hline PBS20 & 1,592 & 2.5 & $8-15$ & 193,523 & Selatan & 109,287 & $-0,353$ & Pancang \\
\hline PBS21 & 1,592 & 2.6 & $25-40$ & 193,579 & Selatan & 109,287 & $-0,353$ & Pancang \\
\hline PBS22 & 1.433 & 2 & $8-15$ & 193,690 & Selatan & 109,287 & $-0,353$ & Pancang \\
\hline PBS23 & 3,503 & 5 & $8-15$ & 193,715 & Selatan & 109,287 & $-0,353$ & Pancang \\
\hline PBS24 & 3,184 & 4.8 & $8-15$ & 193,914 & Selatan & 109,287 & $-0,353$ & Pancang \\
\hline PBS25 & 2,547 & 4.2 & $8-15$ & 193,984 & Selatan & 109,287 & $-0,353$ & Pancang \\
\hline PBS26 & 2,547 & 4 & $8-15$ & 193,995 & Selatan & 109,287 & $-0,353$ & Pancang \\
\hline PBS27 & 1,910 & 2 & $8-15$ & 194,051 & Selatan & 109,287 & $-0,353$ & Pancang \\
\hline PBS28 & 1.433 & 3.2 & $8-15$ & 194,054 & Selatan & 109,287 & $-0,353$ & Pancang \\
\hline PBS29 & 2,229 & 4 & $8-15$ & 194,087 & Selatan & 109,287 & $-0,353$ & Pancang \\
\hline PBS30 & 0,955 & 2 & $15-25$ & 194,092 & Selatan & 109,287 & $-0,353$ & Pancang \\
\hline PBS31 & 1.687 & 4 & $8-15$ & 194,097 & Selatan & 109,287 & $-0,353$ & Pancang \\
\hline PBS32 & 0 & 1.08 & $8-15$ & 194,107 & Selatan & 109,287 & $-0,353$ & Semai \\
\hline PBS33 & 0 & 0.24 & $8-15$ & 194,353 & Selatan & 109,287 & $-0,353$ & Semai \\
\hline PBS34 & 0 & 0.28 & $8-15$ & 194,368 & Selatan & 109,287 & $-0,353$ & Semai \\
\hline PBS35 & 0 & 0.70 & $8-15$ & 194,422 & Selatan & 109,287 & $-0,353$ & Semai \\
\hline PBS36 & 2,866 & 5 & $8-15$ & 194,487 & Selatan & 109,287 & $-0,353$ & Pancang \\
\hline PBS37 & 2,866 & 5.1 & $8-15$ & 194,788 & Selatan & 109,287 & $-0,353$ & Pancang \\
\hline PBS38 & 3,184 & 6 & $8-15$ & 195,235 & Selatan & 109,287 & $-0,353$ & Pancang \\
\hline PBS39 & 3,184 & 5.9 & $8-15$ & 197,125 & Selatan & 109,287 & $-0,353$ & Pancang \\
\hline PBS40 & 3,503 & 4.8 & $8-15$ & 197,372 & Selatan & 109,287 & $-0,353$ & Pancang \\
\hline PBS41 & 1,592 & 3 & $8-15$ & 197,621 & Selatan & 109,287 & $-0,353$ & Pancang \\
\hline PBS42 & 1,910 & 4 & $8-15$ & 197,727 & Selatan & 109,287 & $-0,353$ & Pancang \\
\hline PBS43 & 2,547 & 4.3 & $8-15$ & 198,028 & Selatan & 109,287 & $-0,353$ & Pancang \\
\hline PBS44 & 2.292 & 5.4 & $8-15$ & 198,619 & Selatan & 109,287 & $-0,353$ & Pancang \\
\hline PBS45 & 2.866 & 4.6 & $8-15$ & 198,691 & Selatan & 109,287 & $-0,353$ & Pancang \\
\hline
\end{tabular}


Tabel 5. Fitogeografi pasak bumi berdasarkan kondisi kelerengan (Fitogeography of pasak Bumi based on slope conditions)

\begin{tabular}{lcccc}
\hline \multirow{2}{*}{ Arah mata angin } & \multicolumn{5}{c}{ Kelerengan \% } \\
\cline { 2 - 5 } & $8-15 \%$ & $15-25 \%$ & $25-40 \%$ & $\sum$ \\
\hline Timur & - & 1 & 16 & 17 \\
Barat & - & 18 & - & 18 \\
Utara & - & - & 11 & 11 \\
Selatan & 35 & 1 & 9 & 45 \\
\hline Jumlah & 35 & 20 & 36 & 91 \\
\hline \multicolumn{1}{c}{ Pasak bumi banyak ditemukan } & terlepas dari faktor lingkungan dan \\
didaerah kelerengan $25-40 \%$ dengan & kondisi hasil tersebut relevan dengan \\
jumlah 36 individu dan paling sedikit & kesimpulan (Barbour et al.1987) bahwa \\
dijumpai di kelerangan 15-25\% dengan & pola distribusi spesies tumbuhan \\
jumlah 20 individu. Karena pada & cenderung mengelompok, sebab \\
kelerengan 25-40\% lebih banyak pasak & tumbuhan bereproduksidengan biji yang \\
bumi ditemukan disekitar induknya & jatuh dekat induknya.
\end{tabular}

Tabel 6. Fitogeografi pasak bumi berdasarkan ketinggian tempat (Fitogeography of pasak Bumi based on place height)

\begin{tabular}{|c|c|c|c|c|c|c|c|c|c|c|c|c|}
\hline \multirow[b]{2}{*}{ Arah mata angin } & \multicolumn{11}{|c|}{ Ketinggian (m dpl) } & \multirow[t]{2}{*}{$\sum$} \\
\hline & $\begin{array}{l}8 \\
\frac{1}{\alpha} \\
\infty\end{array}$ & $\begin{array}{l}0 \\
\overline{1} \\
\stackrel{1}{0}\end{array}$ & $\begin{array}{l}\stackrel{ }{7} \\
\stackrel{1}{I} \\
=\end{array}$ & $\begin{array}{l}0 \\
\frac{1}{1} \\
\stackrel{I}{I}\end{array}$ & $\frac{\stackrel{O}{+}}{\frac{1}{2}}$ & $\begin{array}{l}\stackrel{0}{n} \\
\stackrel{1}{ \pm} \\
\stackrel{ \pm}{ \pm}\end{array}$ & $\begin{array}{l}8 \\
\frac{1}{1} \\
n\end{array}$ & $\frac{9}{\frac{1}{6}}$ & $\frac{\infty}{1}$ & $\frac{8}{\frac{1}{1}}$ & $\begin{array}{l}\stackrel{\overbrace{}}{1} \\
\stackrel{1}{2}\end{array}$ & \\
\hline Barat & - & - & - & - & - & - & 1 & 8 & 7 & 2 & - & 18 \\
\hline Timur & - & 1 & - & 9 & 6 & - & 1 & - & - & - & - & 17 \\
\hline Utara & 1 & 7 & 3 & - & - & - & - & - & - & - & - & 11 \\
\hline Selatan & - & - & - & - & - & - & - & - & - & 6 & 39 & 45 \\
\hline Jumlah & 1 & 8 & 3 & 9 & 6 & 0 & 2 & 8 & 7 & 8 & 39 & 91 \\
\hline
\end{tabular}

Berdasar tabel diatas tersebut pasak bumi banyak terdapat pada rentang ketinggian paling atas yaitu antara 191$200 \mathrm{~m}$ dpl.Berdasarkan histogram ketinggian dibawah ini pasak bumi dapat ditemukan pada daerah dengan rentang ketinggian antara 98-200 m dpl dengan jumlah yang paling banyak dijumpai pada daerah dengan rentang ketinggian antara 191-200 $\mathrm{m}$ dpl dengan jumlah 39 individu dan paling sedikit ditemukan pada daerah dengan rentang ketinggian antara 98-100 m dpl dengan jumlah 1 individu. 


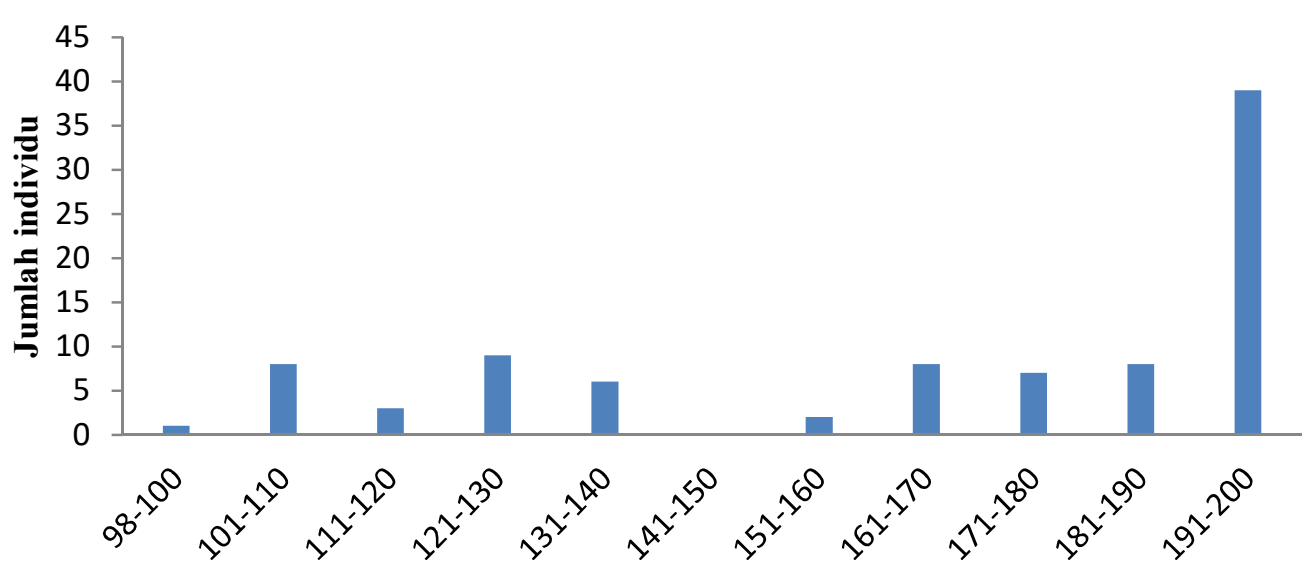

Kelas ketinggian (m dpl)

Gambar 1.Grafik kondisi ketinggian (Graph of altitude conditions)

Tabel 7. Fitogeografi pasak bumi berdasarkan arah mata angin (Fitogeography of pasak Bumi based on the direction of the wind)

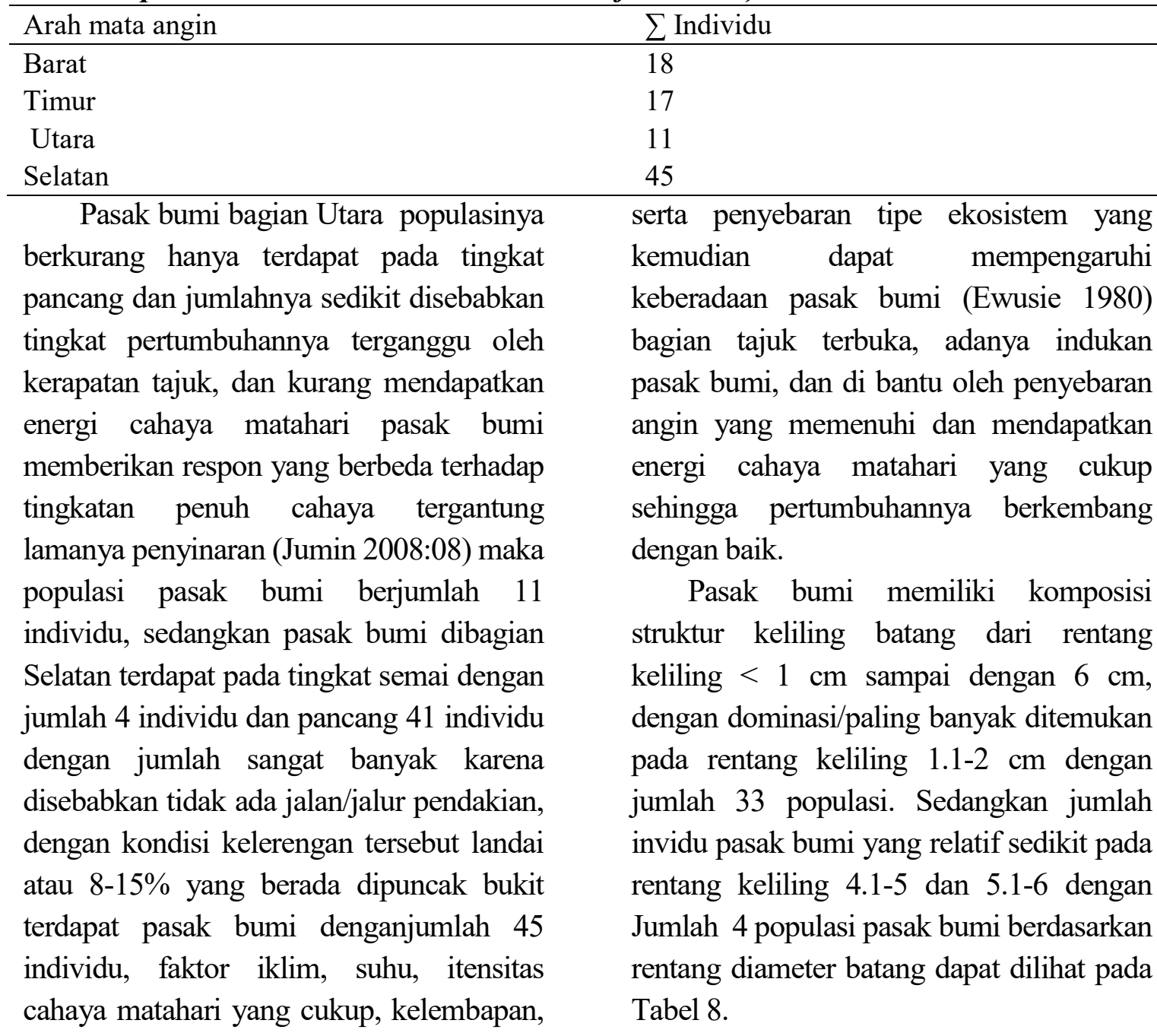


Tabel 8 . Fitogeografi berdasarkan diameter batang pasak bumi (Phytogeography based on the diameter of the stem of the earth post)

\begin{tabular}{llllllll}
\hline \multirow{2}{*}{ Arah mata angin } & \multicolumn{7}{c}{ Diameter batang $(\mathrm{cm})$} \\
\cline { 2 - 7 } & $0-1$ & $1.1-2$ & $2.1-3$ & $3.1-4$ & $4.1-5$ & $5.1-6$ & $\Sigma$ \\
\hline Barat & 2 & 5 & 5 & 4 & 1 & 1 & 18 \\
Timur & - & 3 & 6 & 4 & 2 & 2 & 17 \\
Utara & - & 8 & 2 & 1 & - & - & 11 \\
Selatan & 8 & 17 & 11 & 7 & 1 & 1 & 41 \\
\hline Jumlah & 10 & 33 & 24 & 16 & 4 & 4 & 91 \\
\hline
\end{tabular}

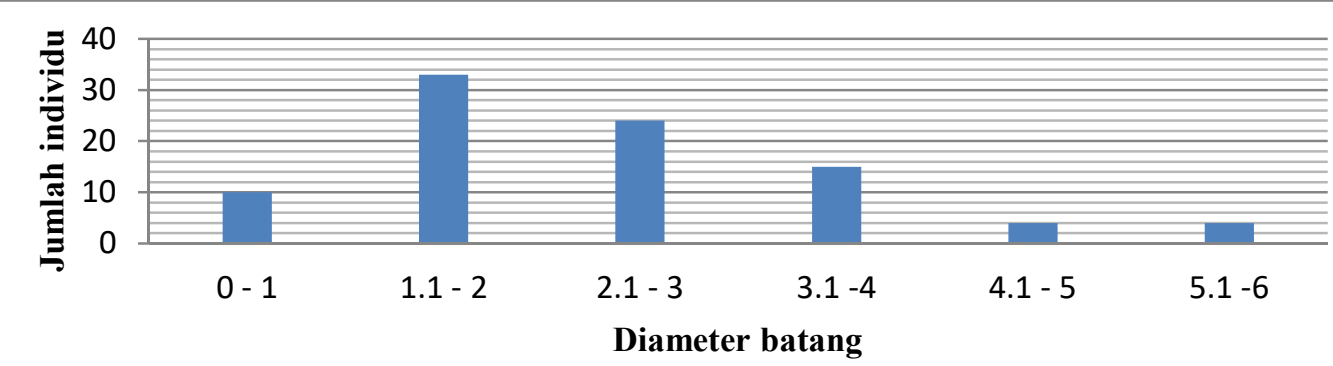

Gambar 2. Grafik berdasarkan diameter batang pasak bumi (Graph-based on the diameter of the earth post stem)

Berdasarkan grafik batang diatas secara ekologis struktur tersebut mengambarkan bahwa populasi pasak bumi normal, karena hutan dalam suatu vegetasi yang normal ditunjukan dengan bentuk kurva "J" terbalik, artinya jumlah semai lebih banyak dibandingkan dengan pancang (Odum1971).
Sedangkan komposisi struktur tingginya berkisar $0.24 \mathrm{~m}$ sampai dengan $7 \mathrm{~m}$, yang dominasi/paling banyak ditemukan pada rentang tinggi antara 2.1-3 $\mathrm{m}$ dengan jumlah 25 individu sedangkan diameter 6.1-7 $\mathrm{m}$ dengan jumlah 2 individu pasak bumi berdasarkan rentang tinggi batang dapat dilihat pada Tabel 9.

Tabel 9. Fitogeografi pasak bumi berdasarkan tinggi batang (Fitogeography of pasak Bumi based on stem height)

\begin{tabular}{lllllllll}
\hline \multirow{2}{*}{ Arah mata angin } & \multicolumn{7}{c}{ Tinggi $(\mathrm{m})$} & \multirow{2}{*}{$\sum$} \\
\cline { 2 - 9 } & $0.24-1$ & $1.1-2$ & $2.1-3$ & $3.1-4$ & $4.1-5$ & $5.1-6$ & $6.1-7$ & \\
\hline Barat & - & - & 7 & 4 & 4 & 2 & 1 & 18 \\
Timur & 1 & 3 & 3 & 7 & 1 & 1 & 1 & 17 \\
Utara & - & 4 & 5 & - & 1 & 1 & - & 11 \\
Selatan & 3 & 11 & 10 & 6 & 10 & 5 & - & 45 \\
\hline Jumlah & 4 & 18 & 25 & 17 & 16 & 9 & 2 & 91 \\
\hline
\end{tabular}




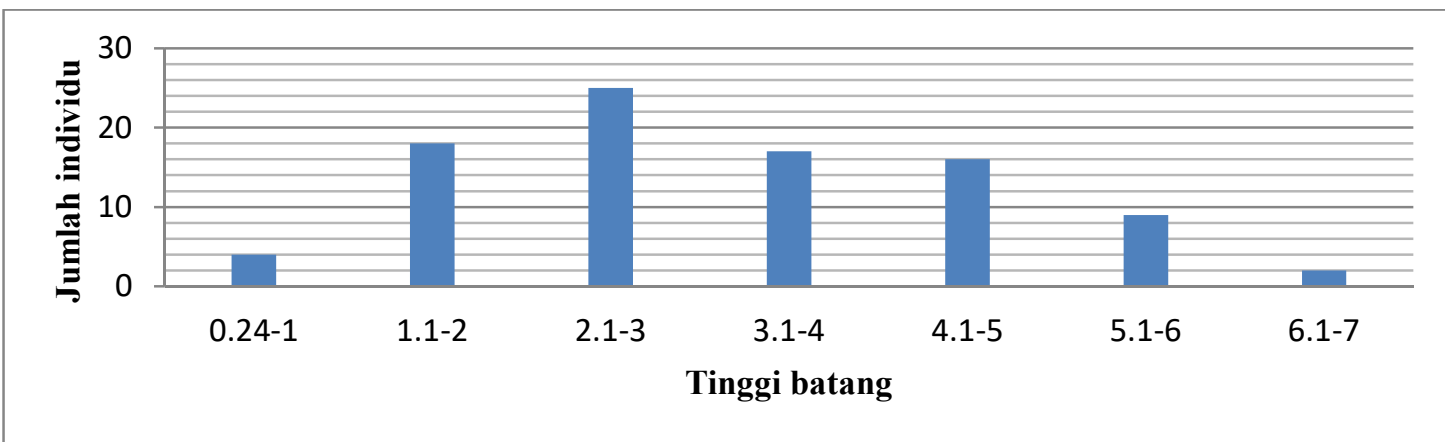

Gambar 3. Grafik berdasarkan tinggi batang pasak bumi (Graphs based on the height of the earth post stem)

Berdasarkan grafik batang diatas sama dengan kecilnya populasi pasak bumi berdasar keliling batang, dimana populasi berdasarkan tinggi batang menunjukan populasi pasak bumi normal dengan bentuk kurva "J" terbalik.

Selama melakukan penelitian dilapangan ditemukan pasak bumi dari tingkat semai sampai tingkat pancang. Tingkat pancang pasak bumi yang paling banyak ditemukan dilapangan tumbuh diberada sekitar induknya. Dari hasil penelitian (Julisasi 1992) menerangkan bahwa berdasarkan penyebaran tempat tumbuh anakan pasak bumi dapat dicirikan pola regenerasi tumbuhan ini adalah mengelompok di sekitar pohon induk.Hal ini sesuai dengan pernyataan dari (Nooteboom 1962) yang menerangkan bahwa pasak bumi merupakan tumbuhan yang berbunga dan berbuah sepanjang tahun.

\section{Kesimpulan}

1. Fitogeografi pasak bumi (Eurycoma longifolia,Jack.) banyak ditemukan pada bagian puncak bukit pada kelerengan berkisar $25-40 \%$ dan ditemukan pada bagian sebelah Selatan bukit sebanyak 45 individu.

2. Fitogeografi pasak bumi (Eurycoma longifolia, Jack) terbatas dijumpai, pada ketinggian $270 \quad \mathrm{~m} \quad \mathrm{dpl}$ disebabkan oleh tidak adanya akses jalan, dan banyak tebing di sekitar penelitian.

\section{Saran}

1. Sebaiknya tumbuhan pasak bumi perlu dilakukan budidaya, karena mengingat jumlahnya yang semangkin berkurang.

2. Lembaga masyarakat yang mengelola Gunung Ambawang Bukit Bendera, diharapkan mengontrol setiap pengunjung yang akan mendaki supaya mereka tidak mengambil tumbuhan pasak bumi yang ada disekitar Bukit Bendera.

\section{DAFTAR PUSTAKA}

Barbour GM, JK Busk and WD Pitts. 1987. Terrestrial Plant Ecology. New York: The Benyamin/Cummings Publishing Company, Inc.

Ewuise JY. 1980. Pengantar Ekologi Tropika. Tanuwidjaya Usman, penerjemah. Bandung: ITB Press. Terjemahan dari: Elements of Trofical Ecology 
Heyne, K. 1987. Tumbuhan Obat Berguna Jilid I-III. Jakarta: Badan Litbang Kehutanan Departemen Kehutanan.

Julisasi, Tri Hadiah. 1992. Kajian Ekologis Pasak Bumi(Eurycoma longifolia Jack.) di Areal HPH PT. Siak Raya Timber Riau. Skripsi. Jurusan Konservasi Sumberdaya Hutan Fakultas Kehutanan Institut Pertanian Bogor. Bogor. $\quad \underline{\text { Tidak }}$ dipublikasikan

Jumin, H.B. 2008. Dasar-Dasar Agronomi. Jakarta: PT Rajagrafindo Persada.

Kartikawati SM, 2014 Habitat preferences, distribution pattern, and root weigh estimation of Pasak Bumi (Eurycoma longifolia, Jack.). JMHT Vol. XX, (1): $43-50$

Nooteboom, H.P . 1962. Flora Malesiana: Menispermaceae, Simarubaceae, Rubiaceae, dan Rulaceae. Bogor: Herbarium Bogorience
Nuryamin Amin .2000. Studi Potensi Obat Akar Kuning (Arcangelisia flava(L) Merr, Pasak Bumi (Eurycoma longifolia Jack). Seluang Belum (luvunga eleuherandra Dalz.) dan Gingseng Kalimantan (Psychotria valentonii Hochr) di Areal HPH Manimbun Djaja (Djajanti Group) Kalimantan Tengah. Bogor: Institut Pertanian Bogor.

Odum, E. P., 1971. Dasar-Dasar Ekologi. Edisi Ketiga. Yogyakarta: Gadjah Mada University Press.

Padua LSN, Bunyapraphatsam, dan Lemmens RHMJ. 1999. Medicinal and poison Plants I. Plant Resources of South-East Asia

Siregar L, Keng CL, Lim BP. 2003. Selection of cell source and the effect of $\mathrm{pH}$ and MS macronutrients on biomass production in cell cultures of ( Eurycoma longifolia Jack). Journal of Plan Biotechnology, $5(2): 125-130$ 